\title{
Breeding areas and southbound migrations of southern minke whales Balaenoptera acutorostrata
}

\author{
Fujio Kasamatsu*, Shigetoshi Nishiwaki, Hajime Ishikawa \\ Institute of Cetacean Research, 4-18 Toyomi, Chuo, Tokyo 104, Japan
}

\begin{abstract}
Southern minke whales Balaenoptera acutorostrata are genetically separated from Northern Hemisphere minke whales. Seasonal migrations take them from tropical latitudes in winter to high latitudes of the Antarctic in summer. Breeding takes place in warmer waters but little is known of breeding areas. Breeding areas and southbound migrations were studied using sighting data derived from the Japanese sighting surveys during 1976 to 1987. Relatively higher concentrations were observed in the waters mainly around $10^{\circ}$ to $20^{\circ} \mathrm{S}$ in October, the end of the main conception period of this species in the Southern Hemisphere. Spatial distribution in tropical and subtropical waters during the latter half of the conception period suggests that there are 2 breeding areas in the eastern and western South Pacific and 2 others in the eastern and western Indian Ocean. It appears that breeding populations of the southern minke whale are relatively dispersed in open waters while coastal species such as right whales Eubalaena glacialis, humpback whales Megaptera novaeangliae and gray whales Eschrichtius robustus migrate along the shore and congregate in near-shore breeding areas. Latitudinal occurrences by month suggest that southern minke whales moved southward from the breeding areas by October-November, and that most of them had migrated into Antarctic waters by January. They tend to move almost directly south from the breeding areas to feeding areas, and subsequently disperse after arriving at the feeding areas. Southbound migration speeds were estimated to average 20 nautical miles ( $\mathrm{n}$ miles) $\mathrm{d}^{-1}$ in waters north of the subtropical convergence and 40 to $50 \mathrm{n}$ miles $\mathrm{d}^{-1}$ in waters south of the convergence.
\end{abstract}

KEY WORDS: Southern minke whale $\cdot$ Balaenoptera acutorostrata $\cdot$ Breeding area $\cdot$ Migration Population cycles

\section{INTRODUCTION}

All larger southern balaenopterids except Bryde's whale Balaenoptera edeni are thought to undertake seasonal migrations between winter breeding areas in tropical or subtropical waters and summer feeding areas in the Southern Ocean (Mackintosh 1942, 1966). In the case of the southern minke whale $B$. acutorostrata, direct and indirect evidence of migration has come from 2 mark recoveries between the Antarctic and Brazil and from the presence of diatoms on the skin of southern minke whales (Nemoto et al. 1980, Best 1982, Buckland \& Duff 1989).

\footnotetext{
- Present address: Marine Ecology Research Institute, Teikoku-shoin Bldg, 3-29 Jinbo-cho, Kanda, Chiyoda, Tokyo 101, Japan
}

Since 1978, as a consequence of the International Whaling Commission International Decade of Cetacean Research (IWC/IDCR) Southern Hemisphere Minke Whale Assessment Cruises, enormous amounts of data have accumulated concerning the distribution and abundance of southern minke whales in their Antarctic feeding areas (Best \& Butterworth 1980, Kasamatsu et al. 1988). At the same time, large amounts of data and materials have accumulated from whaling on this species, which began in 1971 (Ohsumi \& Masaki 1975, Ohsumi 1979, Kasamatsu \& Ohsumi 1981, Kato 1982). Compared with this accumulation of information from the Antarctic, and despite useful studies in coastal waters off Durban, South Africa (Best 1982), off Costinha, Brazil (Williamson 1975), and in the Indian Ocean (Gambell et al. 1975), information concerning distribution, abundance and breeding areas of the 
southern minke whales in low latitudes has been surprisingly limited.

The purpose of the present study was to identify breeding areas and describe southbound migrations of southern minke whales. It was based mainly on sighting data from surveys in the Southern Hemisphere since 1976 .

While 2 forms of minke whales, the 'dark-shoulder' form and the 'diminutive' or 'dwarf' form, were recently identified in the Southern Hemisphere (Best 1985, Arnold et al. 1987), only the more abundant 'dark-shoulder' form was considered for this study.

\section{MATERIALS AND METHODS}

Sighting surveys and data. Since 1976 Japan has been conducting sighting and marking surveys in the Southern Hemisphere from October to March using 2 or 3 sighting vessels, independent of whaling operations (Ohsumi \& Yamamura 1982). The vessels used are all converted whale catchers ( 750 to 900 gross tons) and thus are ideally suited for whale sighting surveys. While searching, the vessels normally kept a constant speed of 12 knots. A constant watch for whales was maintained from sunrise to sunset each day when weather permitted [normally wind speed was less than 22 knots $\mathrm{h}^{-1}$ (or Beaufort Scale 5 or less) and cue visibility more than 1.5 nautical miles ( $n$ miles)]. There were always 2 principal observers on watch in the barrel of the foremast. These observers had the primary responsibility to find whales. In addition, there were always 2 or 3 crew members present on the upper bridge. All these observers, and particularly those in the barrel, used $7 \times 50$ binoculars for scanning the sea ahead of and up to $90^{\circ}$ on either side of the vessel's bow. The vessels traveled along pre-decided tracklines. When a whale or group of whales was seen, the vessel closed with the animals at a speed of 15 knots. After closing with the animals, the species and number was ascertained. In addition to this, a chronological account of the vessel's activities for the searching effort and weather conditions was recorded in the ship's logbook by the officer on watch. At the end of each day, the officer extracted total search distances for that day and total number of whales seen by species. This information was recorded on the sighting format with other information such as noon position, weather and sea surface temperature at noon.

With the exception of the whaling grounds off Costinha in Brazil $\left(7^{\circ} \mathrm{S}\right)$ and possibly Durban in South Africa $\left(30^{\circ} \mathrm{S}\right)$, locations of breeding grounds of southern minke whales have not been well identified. Since there were few observations of northward movements of southern minke whales in waters off Costinha
(Williamson 1975) and a predominance of the northerly moving animals in the mating season off Durban (Best 1982), we guessed that breeding areas might be located between these latitudes, possibly between $5^{\circ}$ and $30^{\circ} \mathrm{S}$. Thus, sightings anywhere north of $30^{\circ} \mathrm{S}$ were considered useful for identifying the breeding areas

The conception season of southern minke whales is considered to be from July to December with the peak in August to October (Best 1982, Kato 1990) and nearly half of conceptions occur from October to December (Kato 1990). The first half of the survey period (October to December) is thought to have coincided with the latter half of the conception season of this species. However, the second half of the survey period (January to March) did not cover the conception season. Therefore, only the sightings data from October to December were used to identify the breeding areas. Southbound migrations were analyzed on the basis of spatial and temporal density variations in all latitudes and periods.

Encounter rate. To analyze temporal and spatial occurrences of southern minke whales, encounter rate number of whales seen per $1 \mathrm{n}$ mile distance searched) was used as an index of density. The coefficient of variation (CV) of the encounter rate was calculated, based on variation of distance searched and number of whales seen by day. The encounter rate $(n / L)$ and its $C V$ were calculated as follows:

$$
\widehat{\mathrm{CV}}\left(\frac{\mathrm{n}}{L}\right)^{2}=\left(\frac{k}{\mathrm{n}_{i}}\right)^{2} \frac{1}{k(k-1)} \sum_{j=1}^{k}\left(n_{1}-\frac{\mathrm{n}}{L} L_{i}\right)^{2}
$$

where $n$ is the total number of whales seen, $L$ is the total distance searched, $k$ is the number of research days, $n_{i}$ is the number of whales seen in $i$ days, and $L_{1}$ is the distance searched in $i$ days (Kasamatsu et al. 1990, Kishino et al. 1991).

\section{RESULTS}

\section{Breeding areas}

Total search distance by $10^{\circ}$ squares of latitude and longitude, between the equator and $30^{\circ} \mathrm{S}$, from October to December are presented in Fig. 1 and those with number of whales seen in Table 1 . Since search efforts were not distributed homogeneously in the study area, relationships between search distance and relative density (encounter rate) were investigated. There was no significant relationship (the regression slopes are not significantly different from zero at the $5 \%$ level) between those values in $10^{\circ}$ squares in any cases. It is, therefore, assumed for the present calculations that 

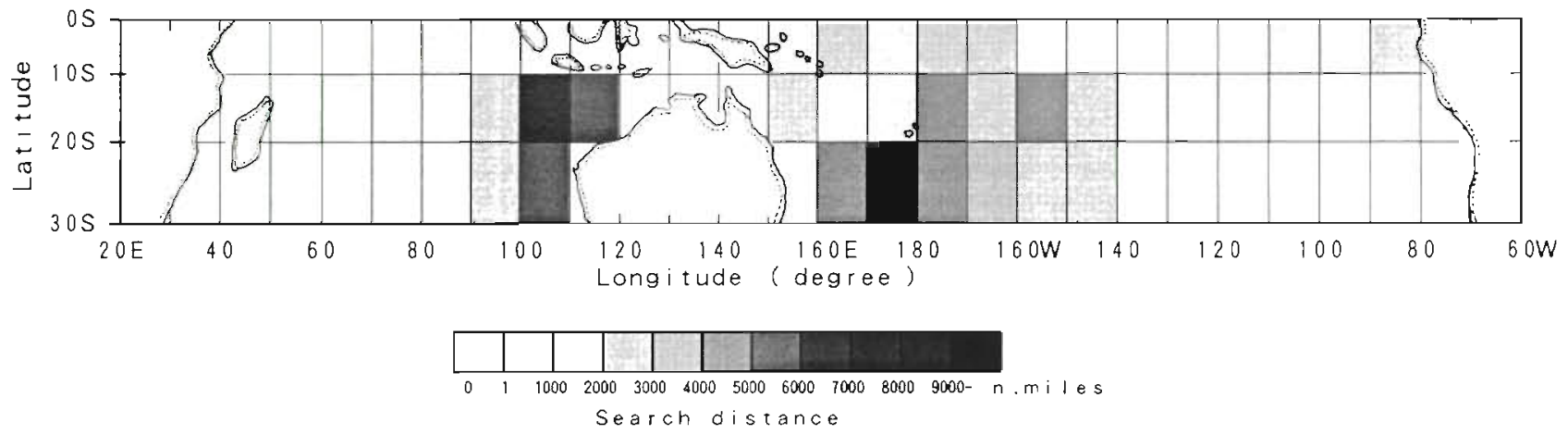

Fig. 1. Distances searched by $10^{\circ}$ squares of latitude and longitude in waters $0^{\circ}$ to $30^{\circ} \mathrm{S}$ from October to December

there is no relationship between search efforts and southern minke whale density and that an unstratified estimate of density should be unbiased in this respect.

A total of $26333 \mathrm{n}$ miles was surveyed in October in waters north of $30^{\circ} \mathrm{S}, 65719 \mathrm{n}$ miles in November and $20140 \mathrm{n}$ miles in December. A total of 57 minke whales were seen in the waters in October, 166 in November and 30 in December.
Encounter rates in $10^{\circ}$ squares are illustrated in Fig. 2. They ranged from 0 to 0.0154 whale per $n$ mile searched with a mean of $0.0023(\mathrm{CV}=0.09$, or $9 \%)$.

In October, higher encounter rates $(>0.003$ whale per $\mathrm{n}$ mile) were in waters $0^{\circ}-10^{\circ} \mathrm{S}, 90^{\circ}-100^{\circ} \mathrm{E}$ and $10^{\circ}-20^{\circ} \mathrm{S}, 100^{\circ}-110^{\circ} \mathrm{E}$ in the eastern Indian Ocean, and in waters $10^{\circ}-20^{\circ} \mathrm{S}, 150^{\circ}-180^{\circ} \mathrm{W}$ in the western South Pacific. Effort in the area $0^{\circ}-10^{\circ} \mathrm{S}, 90^{\circ}-100^{\circ} \mathrm{E}$

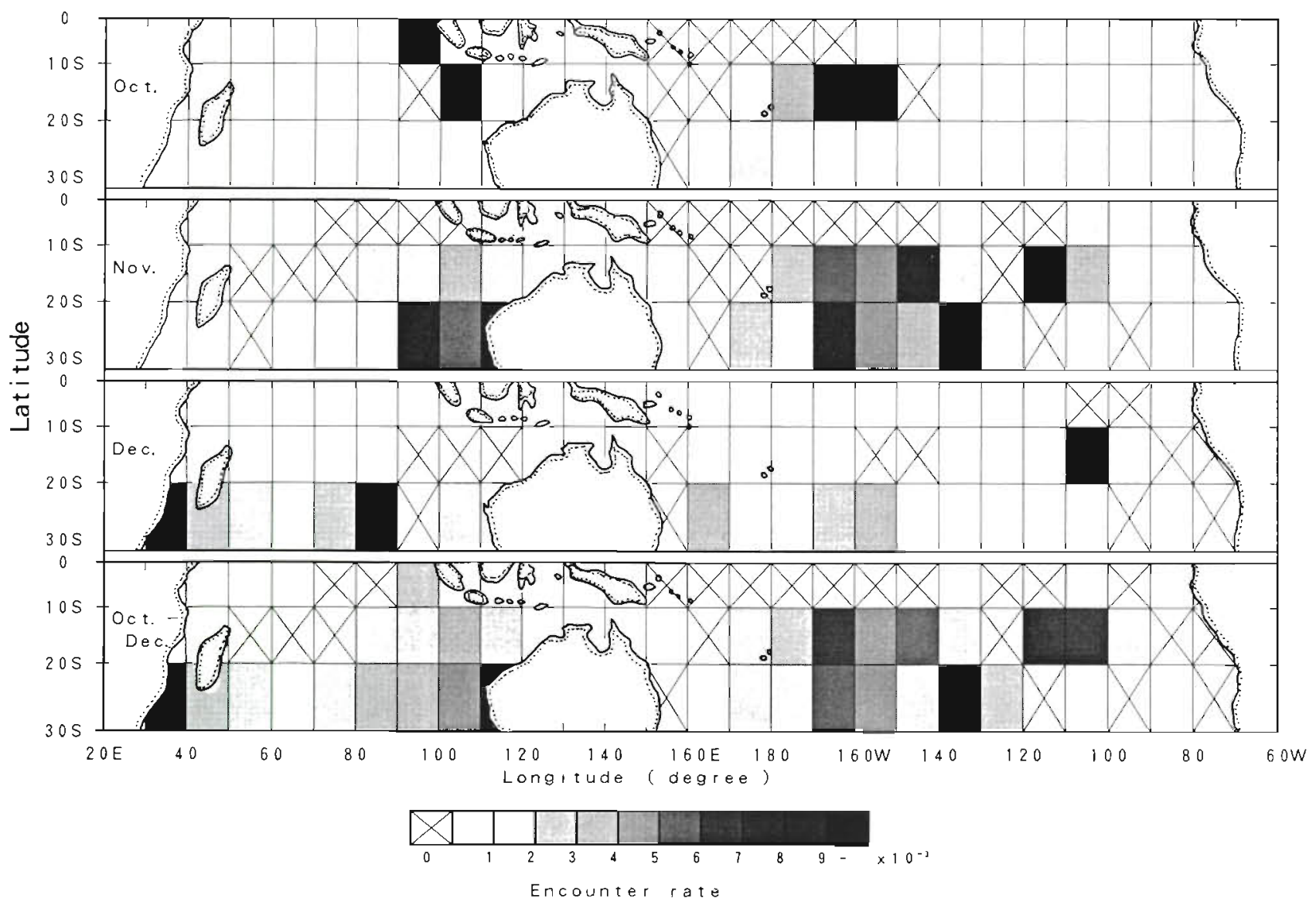

Fig. 2. Balaenoptera acutorostrata. Encounter rates in $10^{\circ}$ squares of latitude and longitude in waters $0^{\circ}$ to $30^{\circ} \mathrm{S}$ 
Table 1. Balaenoptera acutorostrata. Number of whales seen, search distances and encounter rates with coefficient of variation (CV) in waters $0^{\circ}$ to $30^{\circ} \mathrm{S}$ from October to December in 1976 to 1987

\begin{tabular}{|c|c|c|c|c|c|c|c|c|c|}
\hline \multirow[t]{2}{*}{ Longitude } & \multicolumn{3}{|c|}{ No. of whales seen } & \multicolumn{3}{|c|}{ Search distance (n mile) } & \multicolumn{3}{|c|}{ Encounter rate $\left(\times 10^{-3}\right)$ and $(\mathrm{CV})$} \\
\hline & $0^{\circ}-10^{\circ} \mathrm{S}$ & $10^{\circ}-20^{\circ} \mathrm{S}$ & $20^{\circ}-30^{\circ} \mathrm{S}$ & $0^{\circ}-10^{\circ} \mathrm{S}$ & $10^{\circ}-20^{\circ} \mathrm{S}$ & $20^{\circ}-30^{\circ} \mathrm{S}$ & $0^{\circ}-10^{\circ} \mathrm{S}$ & $10^{\circ}-20^{\circ} \mathrm{S}$ & $20^{\circ}-30^{\circ} \mathrm{S}$ \\
\hline \multicolumn{10}{|c|}{ October-December } \\
\hline $30^{\circ}-40^{\circ} \mathrm{E}$ & & & 3 & & & 300 & & & $10(0.65)$ \\
\hline $40^{\circ}-50^{\circ} \mathrm{E}$ & & & 2 & & & 880 & & & $2(0.53)$ \\
\hline $50^{\circ}-60^{\circ} \mathrm{E}$ & & 0 & 2 & & 224 & 1774 & 0 & & \\
\hline $60^{\circ}-70^{\circ} \mathrm{E}$ & & 0 & & & 1328 & & & 0 & \\
\hline $70^{\circ}-80^{\circ} \mathrm{E}$ & 0 & 0 & 2 & 922 & 1634 & 1323 & 0 & 0 & $2(0.61)$ \\
\hline $80^{\circ}-90^{\circ} \mathrm{E}$ & 0 & 2 & 6 & 1001 & 1982 & 1566 & 0 & $1(0.57)$ & $4(0.55)$ \\
\hline $90^{\circ}-100^{\circ} \mathrm{E}$ & 2 & 3 & 8 & 709 & 2150 & 2368 & $3(0.73)$ & $1(0.57)$ & $3(0.54)$ \\
\hline $100^{\circ}-110^{\circ} \mathrm{E}$ & 1 & 24 & 27 & 1734 & 6525 & 5894 & $1(0.95)$ & $4(0.30)$ & $5(0.30)$ \\
\hline $110^{\circ}-120^{\circ} \mathrm{E}$ & 0 & 6 & 5 & 734 & 6100 & 505 & 0 & $1(0.49)$ & $10(0.84)$ \\
\hline $150^{\circ}-160^{\circ} \mathrm{E}$ & 0 & 2 & 0 & 1287 & 2148 & 537 & 0 & $1(0.97)$ & 0 \\
\hline $160^{\circ}-170^{\circ} \mathrm{E}$ & 0 & 0 & 4 & 2018 & 1748 & 4359 & 0 & 0 & $1(0.58)$ \\
\hline $170^{\circ}-180^{\circ}$ & 0 & 2 & 13 & 1093 & 1640 & 6895 & 0 & $1(0.60)$ & $2(0.37)$ \\
\hline $180^{\circ}-170^{\circ} \mathrm{W}$ & 0 & 12 & 5 & 2626 & 4261 & 4739 & 0 & $3(0.40)$ & $1(0.50)$ \\
\hline $170^{\circ}-160^{\circ} \mathrm{W}$ & 0 & 19 & 18 & 2660 & 2741 & 3052 & 0 & $7(0.34)$ & $6(0.29)$ \\
\hline $160^{\circ}-150^{\circ} \mathrm{W}$ & 0 & 19 & 12 & 248 & 4052 & 2893 & 0 & $5(0.29)$ & $4(0.30)$ \\
\hline $150^{\circ}-140^{\circ} \mathrm{W}$ & 0 & 14 & 4 & 251 & 2581 & 2030 & 0 & $5(0.43)$ & $2(0.66)$ \\
\hline $140^{\circ}-130^{\circ} \mathrm{W}$ & & 9 & 9 & & 1333 & 988 & & $2(1.01)$ & $9(0.50)$ \\
\hline $130^{\circ}-120^{\circ} \mathrm{W}$ & 0 & 0 & 2 & 375 & 1590 & 737 & 0 & 0 & $2(0.91)$ \\
\hline $120^{\circ}-110^{\circ} \mathrm{W}$ & 0 & 9 & 0 & 644 & 1137 & 295 & 0 & $8(0.47)$ & 0 \\
\hline $110^{\circ}-100^{\circ} \mathrm{W}$ & 2 & 9 & & 1940 & 1273 & & $1(0.63)$ & $7(0.48)$ & \\
\hline $100^{\circ}-90^{\circ} \mathrm{W}$ & 0 & 1 & 0 & 1527 & 658 & 252 & 0 & $2(0.87)$ & 0 \\
\hline $90^{\circ}-80^{\circ} \mathrm{W}$ & 2 & 0 & & 2239 & 1341 & & $1(0.63)$ & 0 & \\
\hline $80^{\circ}-70^{\circ} \mathrm{W}$ & 0 & 0 & 0 & 122 & 553 & 1676 & 0 & 0 & 0 \\
\hline \multicolumn{10}{|l|}{ October } \\
\hline $90^{\circ}-100^{\circ} \mathrm{E}$ & 2 & 0 & & 261 & 129 & & $8(0.70)$ & 0 & \\
\hline $100^{\circ}-110^{\circ} \mathrm{E}$ & 1 & 11 & & 598 & 1466 & & $2(0.78)$ & $8(0.35)$ & \\
\hline $110^{\circ}-120^{\circ} \mathrm{E}$ & 0 & 3 & & 136 & 2876 & & 0 & $1(0.67)$ & \\
\hline $150^{\circ}-160^{\circ} \mathrm{E}$ & 0 & 0 & 0 & 128 & 723 & 141 & 0 & 0 & 0 \\
\hline $160^{\circ}-170^{\circ} \mathrm{E}$ & 0 & 0 & 3 & 1080 & 813 & 3471 & 0 & 0 & $1(0.71)$ \\
\hline $170^{\circ}-180^{\circ}$ & 0 & 2 & 8 & 648 & 1252 & 5186 & 0 & $2(0.59)$ & $2(0.47)$ \\
\hline $180^{\circ}-170^{\circ} \mathrm{W}$ & 0 & 6 & 1 & 368 & 1913 & 1468 & 0 & $3(0.55)$ & $1(0.94)$ \\
\hline $170^{\circ} 160^{\circ} \mathrm{W}$ & 0 & 13 & & 169 & 1547 & & 0 & $8(0.36)$ & \\
\hline $160^{\circ}-150^{\circ} \mathrm{W}$ & & 7 & & & 1142 & & & $6(0.41)$ & \\
\hline $150^{\circ}-140^{\circ} \mathrm{W}$ & & 0 & 0 & & 667 & 151 & & 0 & 0 \\
\hline November & & & & & & & & & \\
\hline $50^{\circ}-60^{\circ} \mathrm{E}$ & & 0 & 0 & & 224 & 462 & & 0 & 0 \\
\hline $60^{\circ}-70^{\circ} \mathrm{E}$ & & 0 & & 1328 & & & & 0 & \\
\hline $70^{\circ}-80^{\circ} \mathrm{E}$ & 0 & 0 & 1 & 922 & 1634 & 953 & 0 & 0 & $1(0.86)$ \\
\hline $80^{\circ}-90^{\circ} \mathrm{E}$ & 0 & 2 & 1 & 1001 & 1982 & 1179 & 0 & $1(0.57)$ & $1(0.90)$ \\
\hline $90^{\circ}-100^{\circ} \mathrm{E}$ & 0 & 3 & 8 & 448 & 1755 & 1108 & 0 & $2(0.46)$ & $7(0.52)$ \\
\hline $100^{\circ}-110^{\circ} \mathrm{E}$ & 0 & 13 & 25 & 1136 & 4327 & 4444 & 0 & $3(0.43)$ & $6\{0.32\}$ \\
\hline $110^{\circ}-120^{\circ} \mathrm{E}$ & 0 & 3 & 5 & 598 & 3084 & 505 & 0 & $1(0.68)$ & $10(0.84)$ \\
\hline $150^{\circ}-160^{\circ} \mathrm{E}$ & 0 & 2 & & 1159 & 1181 & & 0 & $2(0.93)$ & \\
\hline $160^{\circ}-170^{\circ} \mathrm{E}$ & 0 & 0 & 0 & 938 & 935 & 620 & 0 & 0 & 0 \\
\hline $170^{\circ}-180^{\circ}$ & 0 & 0 & 5 & 445 & 388 & 1709 & 0 & 0 & $3(0.56)$ \\
\hline $180^{\circ}-170^{\circ} \mathrm{W}$ & 0 & 6 & 2 & 2258 & 2348 & 2189 & 0 & $3(0.59)$ & $1(0.67)$ \\
\hline $170^{\circ}-160^{\circ} \mathrm{W}$ & 0 & 6 & 16 & 2491 & 1194 & 2224 & 0 & $5(0.70)$ & $7[0.31)$ \\
\hline $160^{\circ}-150^{\circ} \mathrm{W}$ & 0 & 12 & 11 & 248 & 2758 & 2630 & 0 & $4(0.37)$ & $4(0.32)$ \\
\hline $150^{\circ}-140^{\circ} \mathrm{W}$ & 0 & 14 & 4 & 251 & 1863 & 1058 & 0 & $8(0.41)$ & $4(0.62)$ \\
\hline $140^{\circ}-130^{\circ} \mathrm{W}$ & & 2 & 9 & & 1333 & 988 & & $2(1.01)$ & $9(0.50)$ \\
\hline $130^{\circ}-120^{\circ} \mathrm{W}$ & 0 & 0 & 2 & 375 & 1590 & 737 & 0 & 0 & $2(0.91)$ \\
\hline $120^{\circ}-110^{\circ} \mathrm{W}$ & 0 & 9 & 0 & 644 & 1137 & 295 & 0 & $8(0.47)$ & 0 \\
\hline $110^{\circ}-100^{\circ} \mathrm{W}$ & 2 & 3 & & 1617 & 882 & & $1(0.61)$ & $3(0.92)$ & \\
\hline $100^{\circ}-90^{\circ} \mathrm{W}$ & & & 0 & & & 144 & & & 0 \\
\hline December & & & & & & & & & \\
\hline $30^{\circ}-40^{\circ} \mathrm{E}$ & & & 3 & & & 300 & & & $10(0.65)$ \\
\hline $40^{\circ}-50^{\circ} \mathrm{E}$ & & & 2 & & & 880 & & & $2(0.53)$ \\
\hline $50^{\circ}-60^{\circ} \mathrm{E}$ & & & 2 & & & 1312 & & & $2(0.56)$ \\
\hline $70^{\circ}-80^{\circ} \mathrm{E}$ & & & 1 & & & 370 & & & $3(0.78)$ \\
\hline $80^{\circ}-90^{\circ} \mathrm{E}$ & & & 5 & & & 387 & & & $13(0.37)$ \\
\hline $90^{\circ}-100^{\circ} \mathrm{E}$ & & 0 & 0 & & 266 & 1260 & & 0 & 0 \\
\hline $100^{\circ}-110^{\circ} \mathrm{E}$ & & 0 & 2 & & 732 & 1450 & & 0 & $1(0.56)$ \\
\hline $110^{\circ}-120^{\circ} \mathrm{E}$ & & 0 & & & 140 & & & 0 & \\
\hline $150^{\circ}-160^{\circ} \mathrm{E}$ & & 0 & 0 & & 244 & 396 & & 0 & 0 \\
\hline $160^{\circ}-170^{\circ} \mathrm{E}$ & & & 1 & & & 268 & & & $4(0.68)$ \\
\hline $180^{\circ}-170^{\circ} \mathrm{W}$ & & & 2 & & & 1082 & & & $2(0.93)$ \\
\hline $170^{\circ}-160^{\circ} \mathrm{W}$ & & & 2 & & & 828 & & & $2(0.55)$ \\
\hline $160^{\circ}-150^{\circ} \mathrm{W}$ & & 0 & 1 & & 152 & 263 & & 0 & $4(0.89)$ \\
\hline $150^{\circ}-140^{\circ} \mathrm{W}$ & & 0 & 0 & & 51 & 821 & & 0 & 0 \\
\hline $110^{\circ}-100^{\circ} \mathrm{W}$ & 0 & 6 & & 323 & 391 & & 0 & $15(0.38)$ & \\
\hline $100^{\circ}-90^{\circ} \mathrm{W}$ & 0 & 1 & 0 & 1.527 & 658 & 108 & 0 & $2(0.87)$ & 0 \\
\hline $90^{\circ}-80^{\circ} \mathrm{W}$ & 2 & 0 & & 2239 & 1341 & & $1(0.63)$ & 0 & \\
\hline $80^{\circ}-70^{\circ} \mathrm{W}$ & 0 & 0 & 0 & 122 & 553 & 1676 & 0 & 0 & 0 \\
\hline
\end{tabular}


was very limited (261 $\mathrm{n}$ miles searched in $2 \mathrm{~d}$ ). In November, the higher encounter rates in the eastern Indian Ocean were in waters $10^{\circ}-20^{\circ} \mathrm{S}, 100^{\circ}-110^{\circ} \mathrm{E}$ and $20^{\circ}-30^{\circ} \mathrm{S}, 90^{\circ}-120^{\circ} \mathrm{E}$. The areas of higher encounter rates in the western South Pacific were relatively dispersed between $10^{\circ}-30^{\circ} \mathrm{S}, 130^{\circ}-170^{\circ} \mathrm{W}$ in November. In the eastern South Pacific, higher encounter rates were in waters $10^{\circ}-20^{\circ} \mathrm{S}, 100^{\circ}-120^{\circ} \mathrm{W}$. In December, higher encounter rates were in waters $20^{\circ}-30^{\circ} \mathrm{S}, 80^{\circ}-90^{\circ} \mathrm{E}$ in the eastern Indian Ocean, and in waters $20^{\circ}-30^{\circ} \mathrm{S}, 30^{\circ}-40^{\circ} \mathrm{E}$ in the western Indian Ocean, while the effort in the waters $20^{\circ}-30^{\circ} \mathrm{S}$, $30^{\circ}-40^{\circ} \mathrm{E}$ of the western Indian Ocean was small (300 $\mathrm{n}$ miles in $2 \mathrm{~d}$ ). In the South Pacific, higher encounter rates were observed in the eastern South Pacific from $10^{\circ}-20^{\circ} \mathrm{S}$ and $100^{\circ}-110^{\circ} \mathrm{W}$. There were no very clear concentrations in other areas.

Since the temporal and spatial variation of search effort makes it difficult to draw clear distribution patterns in waters north of $30^{\circ} \mathrm{S}$ from October to December, the search effort and sightings for the 3 months were pooled (Fig. 2 bottom, Fig. 3). This revealed relatively high encounter rates in the eastern South Pacific $\left(100^{\circ}-120^{\circ} \mathrm{W}\right.$, the highest in $10^{\circ}-20^{\circ} \mathrm{S}, 110^{\circ}-$ $\left.120^{\circ} \mathrm{W}\right)$, in the western South Pacific $\left(170^{\circ}-130^{\circ} \mathrm{W}\right.$, the highest in $20^{\circ}-30^{\circ} \mathrm{S}, 130^{\circ}-140^{\circ} \mathrm{W}$ ), in the western Indian Ocean $\left(30^{\circ}-40^{\circ} \mathrm{E}\right)$ and in the eastern Indian Ocean $\left(80^{\circ}-120^{\circ} \mathrm{E}\right.$, the highest in $20^{\circ}-30^{\circ} \mathrm{S}, 110^{\circ}-$ $\left.120^{\circ} \mathrm{E}\right)$.

A distribution gap was observed between the eastern and western Indian Ocean at $60^{\circ}-70^{\circ} \mathrm{E}$ (Fig. 3). In the South Pacific sector, a relatively lower encounter rate was observed in waters between $120^{\circ}$ and $130^{\circ} \mathrm{W}$ compared with other areas. Since this low density area has been continuously observed in waters $30^{\circ}-50^{\circ} \mathrm{S}$ during the southbound migrations and in waters south of $50^{\circ} \mathrm{S}$ through the early stage of the feeding season (see 'Migration routes' below), we can assume the presence of 2 concentration areas in the South Pacific with a possible boundary at $120^{\circ}-130^{\circ} \mathrm{W}$.

On the basis of the observations, we suggest the possibility that the breeding areas of the southern minke whale populations may not be as concentrated as those of coastal species such as humpback whales Megaptera novaeangliae, right whales Balaena glacialis and gray whales Eschrichtius robustus. The main breeding areas of southern minke whales may be located mainly between $10^{\circ}$ and $20^{\circ} \mathrm{S}$. We suggest that there are at least 4 separate breeding areas, 1 in the eastern South Pacific, 1 in the western South Pacific (main area $150^{\circ}-170^{\circ} \mathrm{W}$ ) with a possible boundary at ca $120^{\circ}-130^{\circ} \mathrm{W}$, and the other 2 in the eastern Indian Ocean (main area $100^{\circ}-110^{\circ} \mathrm{E}$ ) and the western Indian Ocean with a possible boundary at ca $60^{\circ}-$ $70^{\circ} \mathrm{E}$.

It is noteworthy that the vast breeding areas in the western South Pacific (mainly between $170^{\circ}$ and $130^{\circ} \mathrm{W}$ ) are in zones where many islands are located. Also, this area is directly north of Antarctic Area $V$ (International Whaling Commission management area $\left.130^{\circ} \mathrm{E}-170^{\circ} \mathrm{W}\right)$ and west of Area VI $\left(170^{\circ}-145^{\circ} \mathrm{W}\right)$ where the largest population estimates of southern minke whales have been made (International Whaling Commission 1991).

\section{Southbound migration}

To investigate the southbound migration of southern minke whales, we first examined latitudinal occurrence by month. Because the amount of open water south of $60^{\circ} \mathrm{S}$ varied greatly due to recession of the ice edge as the season progressed, the encounter rates do not always reflect the actual abundance there. Thus we also calculated an index of abundance of minke whales on the basis of area size and the encounter rate.

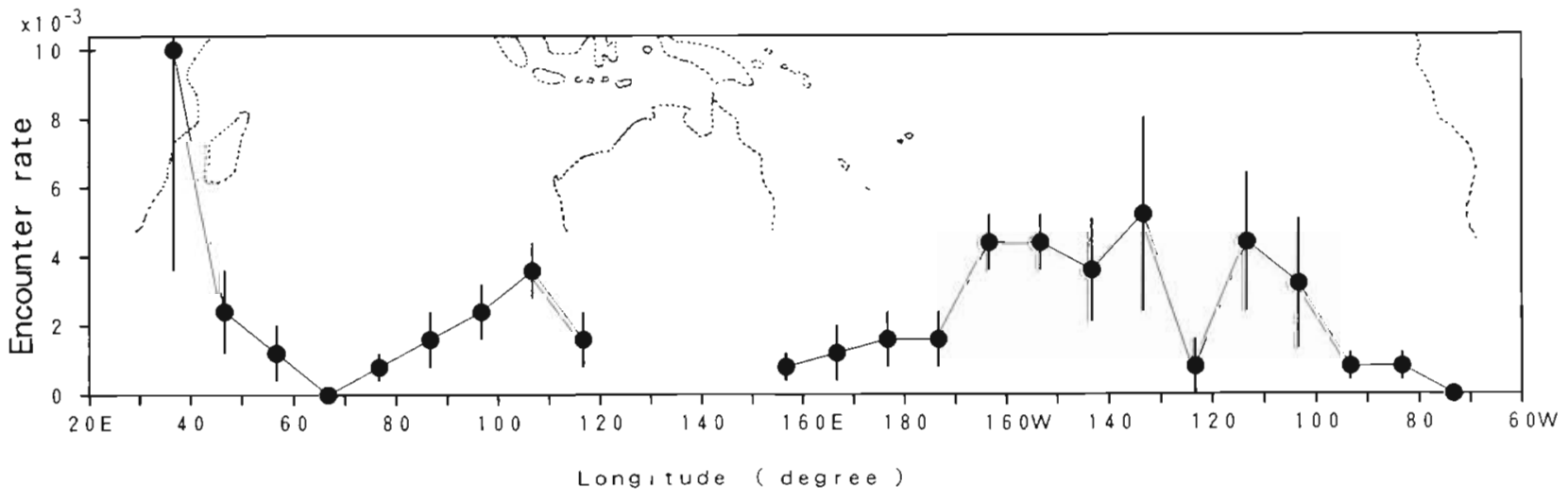

Fig. 3. Balaenoptera acutorostrata. Encounter rates by intervals of $10^{\circ}$ longitude in waters $0^{\circ}$ to $30^{\circ} \mathrm{S}$ from October to December. Vertical lines show the standard errors of the encounter rates 

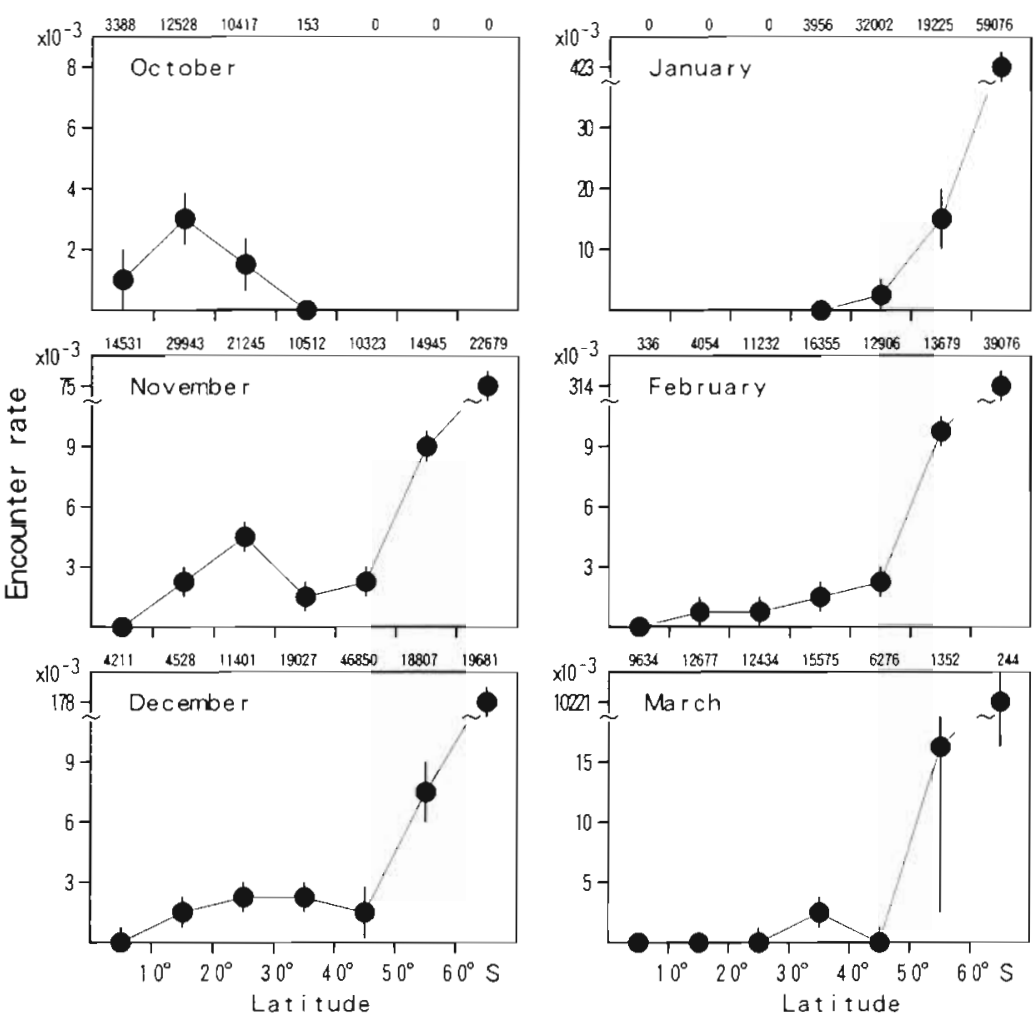

Fig. 4. Balaenoptera acutorostrata. Encounter rates by latitude and by month. Vertical lines show the standard errors of encounter rates. Numbers above panels are total distances searched

The index of abundance $(I)$ is thus calculated as $I=A(\mathrm{n} / L)$, where $A$ is area size.

Fig. 4 shows the encounter rates by month and by intervals of $10^{\circ}$ latitude. The highest rate during October was in waters between $10^{\circ}$ and $20^{\circ} \mathrm{S}$, and this peak shifted to waters between $20^{\circ}$ and $30^{\circ} \mathrm{S}$ during November. Another mode was also observed in waters south of $60^{\circ} \mathrm{S}$ in November.

Fig. 5 shows the distribution of the index of abundance by month and by intervals of $20^{\circ}$ latitude. According to this figure, approximately $40 \%$ of southern minke whales have already migrated into the Antarctic waters by November and about $35 \%$ remain in waters north of $40^{\circ} \mathrm{S}$ in November. We can see a clear shift of abundance of minke whales from the lower latitudinal waters to higher latitudinal waters with time.

In December, the latitudinal distribution was also bimodal (Fig. 4). In waters $30^{\circ}-40^{\circ} \mathrm{S}$ the mode was not clear, compared to those in October and November. The second mode was in waters south of $60^{\circ} \mathrm{S}$. The encounter rate in waters south of $60^{\circ} \mathrm{S}$ increased 2.4 times from that in November. Although no encounter rate data for January in waters north of $30^{\circ} \mathrm{S}$ were available from this study, Gambell et al. (1975) observed a low density of this species in waters between $20^{\circ}$ and $40^{\circ} \mathrm{S}$ in January and February. In addition, we observed a very low encounter rate in waters north of $30^{\circ} \mathrm{S}$ in February and the highest rate in January in the Antarctic waters. From these results, we can assume that more than $90 \%$ of southern minke whales will have migrated into the Antarctic by January (see Fig. 6). In February, encounter rate in the Antarctic decreased slightly and no clear peak was seen in waters north of $60^{\circ} \mathrm{S}$. In March, a small peak was also observed in waters $30^{\circ}-40^{\circ} \mathrm{S}$.

On the basis of these observations, we can assume that a part of the southern minke whale population migrates southward from the waters around $10^{\circ}-20^{\circ} \mathrm{S}$ to the waters around $20^{\circ}-$ $30^{\circ} \mathrm{S}$ during November, arriving in Antarctic waters by January. On the basis of monthly catches and biology in the Antarctic (Ohsumi \& Masaki 1975, Ohsumi 1979, Kasamatsu \& Ohsumi 1981), we suggest that this group is composed of mature animals, mainly pregnant females, and that the group in the Antarctic by November consists mainly of young animals. We note that the first groups of the northbound migration may leave the Antarctic by February and reach waters between $30^{\circ}$ and $40^{\circ} \mathrm{S}$ in March. Such a northbound migration

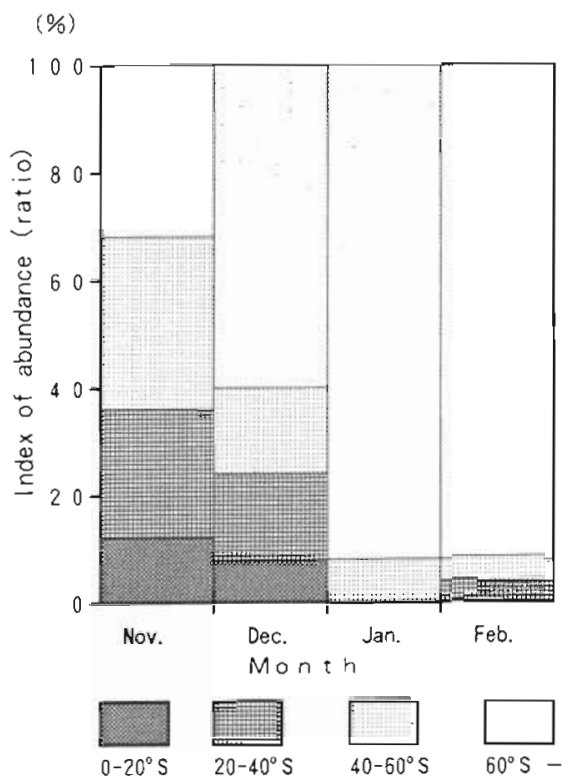

Fig. 5. Balaenoptera acutorostrata. Index of abundance [ratio $=I\left(20^{\circ}-40^{\circ} \mathrm{S}\right) /$ Total $\left.I\right]$ by latitude and by month 


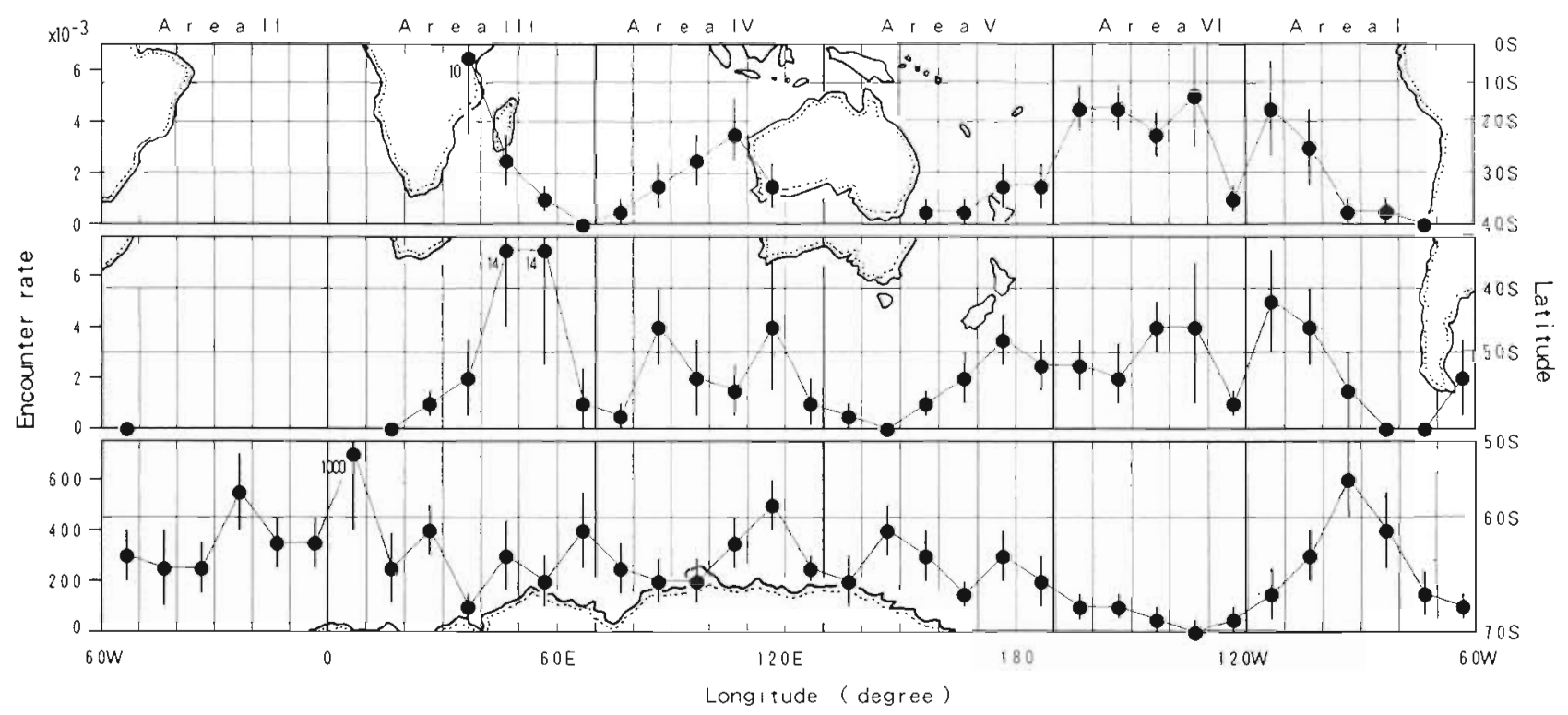

Fig. 6. Balaenoptera acutorostrata. Encounter rates by intervals of $10^{\circ}$ longitude and by month in waters $0^{\circ}$ and $30^{\circ} \mathrm{S}$ from October to December (upper panel), in waters $30^{\circ}$ and $50^{\circ} \mathrm{S}$ from November and December (middle panel), in waters south of $50^{\circ} \mathrm{S}$ during December and January (lower panel). Vertical lines show the standard errors of the encounter rates

pattern would be consistent with the fact that the first minke whales appeared off Durban $\left(30^{\circ} \mathrm{S}\right)$ in March (Best 1982).

\section{Migration routes}

On the basis of longitudinal occurrences by month, we tried to describe the possible migration routes of southern minke whales. Fig. 6 shows the encounter rates by intervals of $10^{\circ}$ longitude in the 3 latitudinal zones. Southern minke whales in the eastern South Pacific breeding area $\left(0^{\circ}-30^{\circ} \mathrm{S}, 120^{\circ}-100^{\circ} \mathrm{W}\right)$ moved southward or south-southeastward and reached Antarctic waters between $120^{\circ}$ and $70^{\circ} \mathrm{W}$. Encounter rates were consistently low in the area around $120^{\circ} \mathrm{W}$ during the southbound migration and feeding periods. Southern minke whales in the western South Pacific moved generally southward but trending towards the west. Those in the eastern Indian Ocean moved southward almost directly, apparently diverging in eastern and western directions around $100^{\circ} \mathrm{E}$. Those in the western Indian Ocean possibly moved southward or south-southeastward. In the Antarctic, it seems that the whales tend to disperse after arriving at the feeding areas. There was no clear peak of the distribution in the Antarctic feeding areas during the main feeding season (January and February) with 1 possible exception of minke whales in the eastern South Pacific. This feature was also recently suggested by mtDNA diversity of this species (Pastene et al. 1993).
From these results, we can probably assume that southern minke whales move generally straight south from the breeding areas to the feeding areas.

\section{Migration speed}

The speed of the southbound migration of southern minke whales was crudely estimated based on the peak of seasonal occurrence by latitude. From the examination of encounter rate by intervals of $5^{\circ}$ latitude by half-month (Table 2), the peak of occurrence in late October was between $15^{\circ}$ and $20^{\circ} \mathrm{S}$ and the peak shifted to between $25^{\circ}$ and $30^{\circ} \mathrm{S}$ in early and late November. In early December, the peak was between $30^{\circ}$ and $35^{\circ} \mathrm{S}$. This progression shows that a component of the population, mainly mature animals, traversed a total of $15^{\circ}$ of latitude ( $900 \mathrm{n}$ miles) in roughly $1.5 \mathrm{mo}$, or an average of about $20 \mathrm{n}$ miles $\mathrm{d}^{-1}$. After mid-December, there was no clear peak in waters north of $60^{\circ} \mathrm{S}$. In contrast, the density of minke whales in Antarctic waters substantially increased from December and the maximum density occurred in late January. This suggests that a component of the minke whale population, mainly mature animals, moved from around $35^{\circ} \mathrm{S}$ in mid-December to south of $60^{\circ} \mathrm{S}$ in January. Such movement indicates an average migration speed of 40 to $50 \mathrm{n}$ miles $\mathrm{d}^{-1}$. Southern minke whales thus may migrate relatively slowly in the waters north of the Subtropical Convergence and increase their speed once having crossed the Conver- 
Table 2. Balaenoptera acutorostrata. Encounter rates $\left(E R, \times 10^{-3}\right)$ with coefficient of variations (CV) by intervals of $5^{\circ}$ latitude and half-month. L: late; E: early

\begin{tabular}{|c|c|c|c|c|c|c|c|c|c|c|c|c|c|c|c|c|c|c|c|c|}
\hline $\begin{array}{l}\text { Latitude } \\
\text { interval }\end{array}$ & & $\begin{array}{l}\text { Oct } \\
\mathrm{CV}\end{array}$ & & $\begin{array}{l}\text { Nov } \\
\text { CV }\end{array}$ & & $\begin{array}{l}\text { Nov } \\
\mathrm{CV}\end{array}$ & & $\begin{array}{l}\text { Dec } \\
\text { CV }\end{array}$ & & $\begin{array}{l}\text { Dec } \\
\text { CV }\end{array}$ & & $\begin{array}{l}\text { Jan } \\
\text { CV }\end{array}$ & & $\begin{array}{l}\mathrm{Jan} \\
\mathrm{CV}\end{array}$ & $\begin{array}{l}E \text {. } \\
E R\end{array}$ & $\begin{array}{l}\text { Feb } \\
\mathrm{CV}\end{array}$ & & $\begin{array}{l}\text { Feb } \\
\text { CV }\end{array}$ & & $\begin{array}{c}\mathrm{Mar} \\
\mathrm{CV}\end{array}$ \\
\hline $0^{\circ}-5^{\circ} \mathrm{S}$ & 0 & - & 0 & - & 0 & - & 0 & - & & & & & & & & & 0 & - & 0 & - \\
\hline $5^{\circ}-10^{\circ} \mathrm{S}$ & 1 & 0.71 & 0 & - & 1 & 0.68 & 1 & 0.67 & & & & & & & & & 0 & - & 0 & - \\
\hline $10^{\circ}-15^{\circ} \mathrm{S}$ & 3 & 0.28 & 1 & 0.39 & 2 & 0.42 & 4 & 0.83 & 0 & - & & & & & & & 0 & -- & 0 & - \\
\hline $15^{\circ}-20^{\circ} \mathrm{S}$ & 4 & 0.31 & 3 & 0.39 & 4 & 0.26 & 0 & - & 0 & - & & & & & & & 1 & 0.61 & 0 & - \\
\hline $20^{\circ}-25^{\circ} \mathrm{S}$ & 1 & 0.49 & 4 & 0.31 & 3 & 0.34 & 1 & 0.72 & 0 & - & & & & & 0 & - & 1 & 0.65 & 0 & - \\
\hline $25^{\circ}-30^{\circ} \mathrm{S}$ & 1 & 0.58 & 5 & 0.28 & 5 & 0.31 & 2 & 0.27 & 0 & - & & & & & 1 & 0.60 & 1 & 0.65 & 1 & 0.57 \\
\hline $30^{\circ}-35^{\circ} \mathrm{S}$ & & & 3 & 0.44 & 2 & 0.53 & 4 & 0.26 & 0 & - & & & 0 & - & 2 & 0.40 & 1 & 0.59 & 4 & 0.79 \\
\hline $35^{\circ}-40^{\circ} \mathrm{S}$ & & & 1 & 0.94 & 1 & 0.68 & 3 & 0.27 & 1 & 0.46 & 0 & - & 0 & - & 0 & - & 1 & 0.51 & 1 & 0.71 \\
\hline $40^{\circ}-45^{\circ} \mathrm{S}$ & & & 2 & 0.45 & 1 & 0.43 & 2 & 0.63 & 3 & 0.52 & 1 & 0.34 & 1 & 0.73 & 2 & 0.50 & 3 & 0.52 & 0 & - \\
\hline $45^{\circ}-50^{\circ} \mathrm{S}$ & & & 0 & - & 5 & 0.43 & 1 & 0.51 & 3 & 0.46 & 4 & 0.43 & 1 & 0.47 & 4 & 0.51 & 1 & 0.58 & 0 & - \\
\hline $50^{\circ}-55^{\circ} \mathrm{S}$ & & & 4 & 0.44 & 7 & 0.37 & 3 & 0.33 & 4 & 0.30 & 0 & - & 2 & 0.46 & 8 & 0.47 & 2 & 0.63 & 5 & 0.81 \\
\hline $55^{\circ}-60^{\circ} \mathrm{S}$ & & & 12 & 0.24 & 14 & 0.21 & 9 & 0.37 & 16 & 0.39 & 23 & 0.27 & 20 & 0.21 & 20 & 0.30 & 9 & 0.36 & 29 & 0.62 \\
\hline$>60^{\circ} \mathrm{S}$ & & & 60 & 0.22 & 77 & 0.12 & 81 & 0.25 & 238 & 0.13 & 392 & 0.11 & 443 & 0.08 & 365 & 0.11 & 275 & 0.24 & & \\
\hline
\end{tabular}

gence. Although there was no previous information on the migration speed of this species, Dawbin (1966) estimated that humpback whales averaged $30 \mathrm{n}$ miles $\mathrm{d}^{-1}$ en route to the Antarctic

\section{DISCUSSION}

The use of sighting information to identify breeding areas was thought to involve 2 problems: first, it is difficult to know whether or not the surveys effectively covered the breeding season of the target species; second, it is necessary to evaluate the significance of sightings during the breeding season in tropical or subtropical waters.

The breeding areas can be generally denoted as areas where mating and/or calving take place. This study mainly examined data from the period of conception (mating season) to identify the breeding areas. The breeding season of southern baleen whales, generally, is considered to be austral winter, generally May to August (Lockyer 1984) but our surveys covered only the period of austral spring-summer (October to March). Therefore, generally it is difficult to identify the breeding areas on the basis of sightings obtained during the non-breeding season. However, as mentioned before, most conceptions are considered to occur from July to December with the peak in August to October (Best 1982, Kato 1990). The first half of the survey period (October to December), therefore, was thought to overlap sufficiently with the latter half of the mating season of southern minke whales such that sighting distribution, especially October, would provide useful insights about breeding areas of southern minke whales.

The observers on survey vessels could not properly determine whether the animals seen were mature or immature. Therefore, another problem is judging whether or not immature whales and resting females migrate into the breeding areas. While Best (1981) suggested that juvenile right whales may be distributed farther off shore than adults during the breeding season off South Africa, little is known of the segregation between mature and immature whales on the breeding grounds for pelagic species such as blue, fin, sei and minke whales. Bannister \& Gambell (1965) observed that immature whales, resting females, pregnant females and lactating females of fin whales Balaenoptera physalus and sei whales $B$. borealis appeared together at the same whaling grounds off Durban while the timing of migration differed according to reproductive class. Williamson (1975) and Best (1982) reported that both mature and immature whales were present on the Brazilian whaling grounds and the Durban whaling grounds, respectively, but that there were clear differences in the timing of migration.

Considering the lack of direct information on segregation by reproductive class, further surveys are needed especially during the main breeding season within the suggested breeding areas.

This study provides information on the breeding areas and the southbound migrations mainly during October to March, but our surveys did not cover the main northbound migration period of this species. The lack of coverage from April to September makes it difficult to draw clear conclusions about the entire migration pattern, or cycle, of southern minke whales. Best (1982) and Holt et al. (1982) described seasonal changes in the abundance of southern minke whales, off Durban $\left(30^{\circ} \mathrm{S}\right)$ and Costinha $\left(7^{\circ} \mathrm{S}\right)$, respectively, Data from the Brazilian land station from June to December indicated increasing abundance from June to October and a rapid decline thereafter (Fig. 7). In the 


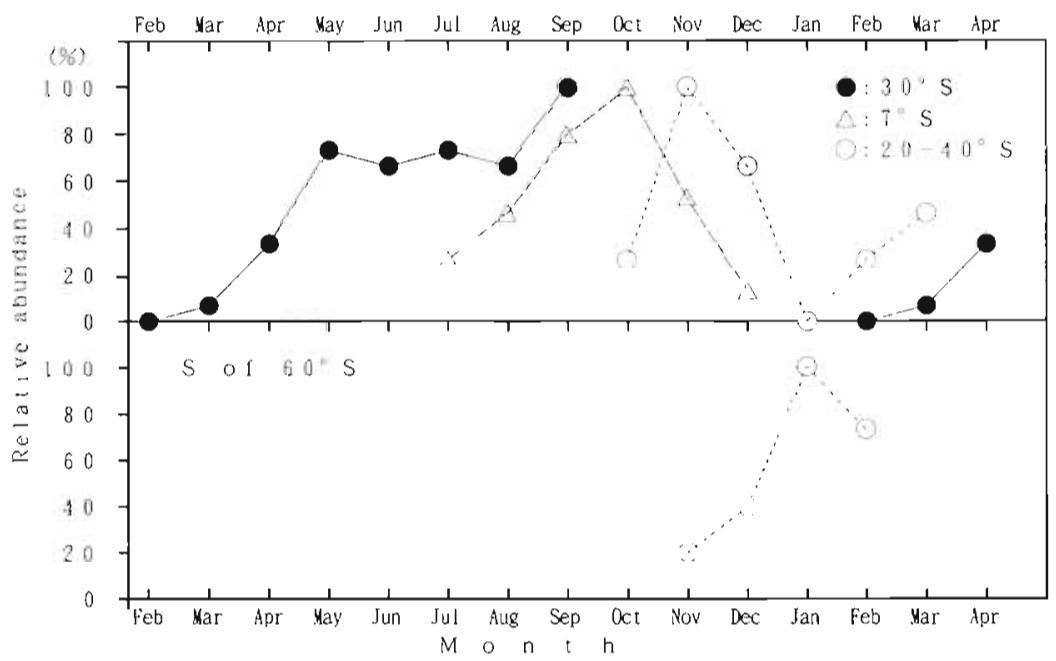

Fig. 7. Balaenoptera acutorostrata. Seasonal abundance of southern minke whales off Brazil (sightings per research hour, relative to October), Durban (whales seen per $12 \times 10^{3}$ miles flown, relative to September), and in waters $20^{\circ}$ to $40^{\circ} \mathrm{S}$ (encounter rate, relative to November) and south of $60^{\circ} \mathrm{S}$ (encounter rate, relative to January)

latitudes $20^{\circ}$ to $30^{\circ} \mathrm{S}$, Japanese sighting data show a declining trend from November to March, and data from Durban indicate increasing density there from February to September. These trends in the 3 sets of data, taken as a whole, are consistent with the hypothesis that southern minke whales undertake regular annual migrations between tropical and polar regions. They can be interpreted as suggesting that younger whales leave the breeding areas earlier than mature ones, while the mature whales and pregnant females depart the breeding areas by approximately October to November; the segment of the population consisting of mainly young whales begins returning to the breeding grounds after February. Most other whales leave the feeding grounds by March, and the northbound migration continues into the early austral winter.

Mackintosh (1966) called attention to the general problems of identifying breeding grounds and suggested the need for direct observations in low latitudes. He raised 2 specific questions: (1) How far do whales travel toward the equator? and (2) Are breeding populations concentrated or dispersed? Little progress has been made since the 1960s toward identifying and characterizing the breeding grounds of pelagic whale species

Effort has been made to identify stocks using various methods, such as analysis of catch distributions in the Antarctic (van Beek \& de la Mare 1982, van Beek 1983), mark-recapture (Buckland \& Duff 1989), comparisons of morphology (Doroshenko 1979, Wada \& Numachi 1979, Bushuev \& Ivashin 1986, Bushuev 1990), isozyme analyses (Wada \& Numachi 1979), and DNA analyses (Hoelzel \& Dover 1989, Wada et al. 1991). However, stock divisions for southern minke whales in the Antarctic have not been well defined. Substantial mixing of individuals of different stocks has been considered in the feeding grounds, where nearly all sampling has taken place. Ours is the first study to provide evidence about the possible separation of stocks and the presence of breeding areas in tropical waters, based on sightings data obtained toward the end of the mating season. We may now be able to answer the 2 questions posed by Mackintosh (1966; see above). Southern minke whales migrate far north, but their main breeding areas are probably between $10^{\circ}$ and $20^{\circ} \mathrm{S}$. The breeding populations of southern minke whales may be relatively dispersed in open waters. This distinguishes them from right, humpback and gray whales, which migrate between near-shore breeding concentration areas and oceanic feeding areas. This difference may suggest differences of meeting probability of mature males and females in the breeding areas between oceanic species such as minke whales and coastal species such as humpback whales

Finally, sighting data do not provide any information on genetic differentiation between the breeding areas. Such information can only be obtained through biological and genetic surveys in the breeding areas during the main breeding season.

Acknowledgements. All vessels were provided by the Fisheries Agency of the Japanese Government and the sightings data were provided by the National Research Institute of Far Seas Fisheries. We are grateful to Dr P. B. Best, Mammal Research Institute, University of Pretoria, Dr S. Ohsumi, Institute of Cetacean Research, and Mr M. Cawthorn, Plimerton, Wellington, New Zealand for their critical and valuable comments on this study. Dr Randall R. Reeves, Deputy Chairman, Cetacean Specialist Group, IUCN and Dr P. G. H. Evans, Dept of Zoology, University of Oxford, read the final manuscript and made valuable suggestions for improvements. The study could not have been undertaken without the assistance and cooperation of the crew and researchers on board the sighting vessels. We also thank 3 anonymous reviewers for their useful suggestions.

\section{LITERATURE CITED}

Arnold, P., Marsh, H., Heinsohn, G. (1987). The occurrence of two forms of minke whales in east Australian waters with a description of external characters and skeleton of the 
diminutive or dwarf form. Sci. Rep. Whales Res. Inst. 38 : $1-46$

Bannister, J. L., Gambell, R. (1965). The succession and abundance of fin, sei and other whales off Durban. Norsk Hvalfangstiid 54: 45-60

Best, P. B. (1981). The status of right whales (Eubalaena glacialis) off South Africa, 1969-1979. Investl. Rep. Sea Fish. Inst. S. Afr. 123: 1-44

Best, P. B. (1982). Seasonal abundance, feeding, reproduction, age and growth in minke whales off Durban (with incidental observations from the Antarctic). Rep. int. Whal. Commn 32: 759-786

Best, P. B. (1985). External characters of southern minke whales and existence of diminutive form. Sci. Rep. Whales Res. Inst. 36: 1-33

Best, P. B., Butterworth, D. S. (1980). Report of the southern hemisphere minke whale assessment cruise, 1978/79. Rep. int. Whal. Commn 30: 257-283

Buckland, S. T., Duff, E. I. (1989). Analysis of the southern hemisphere minke whale mark-recovery data. Rep. int. Whal. Commn (Special Issue) 11: 121-143

Bushuev, S. G. (1990). A study of the population structure of southern minke whale (Balaenoptera acutorostrata Lecepede) based on the analysis of data on the morphological and ecological variability of the species. Rep. int. Whal Commn 40: 317-324

Bushuev, S. G., Ivashin, M. V. (1986). Variation of coloration of Antarctic minke whales. Rep. int. Whal. Commn 36 $193-200$

Dawbin, W. H. (1966). The seasonal migratory cycle of humpback whales. In: Noris, K. S. (ed.) Whales, dolphins and porpoises. Univ, of California Press, Berkeley, p. 145-170

Doroshenko, N. V. (1979). Populations of minke whales in the Southern Hemisphere. Rep. int. Whal. Commn 29 361-365

Gambell, R., Best, P. B., Rice, D. W. (1975). Report on the international Indian Ocean whale marking cruise 24 November 1973-3 February 1974. Rep. int. Whal. Commn 25 $240-252$

Hoelzel, A. R., Dover, G. A. (1989). Molecular techniques for examining genetic variation and stock identity in the cetacean species. Rep. int. Whal. Commn (Special Issue) 11: $81-120$

Holt, S. J., de la Mare, W. K., van Beek, J. G. (1982). A review of information available for the assessment of minke whales in Area II. Rep. int. Whal. Commn 32: 717-721

International Whaling Commission (1991). Report of Scientific Committee. Rep. int. Whal. Commn 41:51-82

Kasamatsu, F., Hembree, D., Joyce, G., Tsunoda, L., Rowlett, R., Nakano, T. (1988). Distribution of cetacean sightings in the Antarctic; results obtained from the IWC/IDCR minke whale assessment cruises, 1978/79-1983/84. Rep. int Whal. Commn 38: 449-487

Kasamatsu, F., Kishino, H., Hiroyama, H. (1990). Estimations of number of minke whale school and individuals based

This article was submitted to the editor on the 1987/88 Japanese feasibility study data. Rep. int Whal Commn 40: 239-247

Kasamatsu, F., Ohsumi, S. (1981). Distribution pattern of minke whales in the Antarctic with special reference to the sex ratio in the catch. Rep. int. Whal. Commn 31: $345-348$

Kato, H. (1982). Some biological parameters for the Antarctic minke whale. Rep. int. Whal. Commn 32: 935-945

Kato, H. (1990). Life cycles of Balaenopteridae, with special reference to southern minke whales. In: Miyazaki, N. Kasuya, T. (eds.) Biology of marine mammals. Scientist Inc, Tokyo, p. 128-150 (in Japanese)

Kishino, H., Kato, H., Kasamatsu, F., Fujise, H. (1991). Detection of heterogeneity and estimation of population characteristics from the field survey data: 1987/88 Japanese feasibility study of the southern hemisphere minke whales. Ann. Inst. Statist. Math. 43: 435-453

Lockyer, C. (1984). Review of baleen whale (Mysticeti) reproduction and implications for management. Rep. int. Whal. Commn (Special Issue) 6: 26-49

Mackintosh, N. A. (1942). The southern stocks of whalebone whales. Discovery Rep. 22: 197-300

Mackintosh, N. A. (1966). The distribution of southern blue and fin whales. In: Noris, K. S. (ed.) Whales, dolphins and porpoises. Univ. of California Press, Berkeley, p. 125-144

Nemoto, T., Best, P. B., Ishimaru, K., Takano, H. (1980). Diatom films on whales in South African waters. Sci. Rep. Whales Res. Inst. 32: 97-103

Ohsumi, S. (1979). Population assessment for the Antarctic minke whale. Rep. int. Whal. Commn 29: 407-420

Ohsumi, S., Masaki, Y. (1975). Biological parameters of the Antarctic minke whale at the virgin population level. J. Fish. Res. Bd Can. 32: 995-1004

Ohsumi, S., Yamamura, K. (1982). A review of the Japanese whale sighting system. Rep. int. Whal. Commn 32: $581-586$

Pastene, L. A., Kobayashi, T, Fujise, Y., Numachi, K. (1993). Mitochondrial DNA differentiation in Antarctic minke whales. Rep. int. Whal Commn 43: 349-355

van Beek, J. G. (1983). A note on the accumulated southern minke whale catch distribution with regard to stock boundaries. Rep. int. Whal. Commn 33: 315-321.

van Beek, J. G., de la Mare, W. K. (1982). Longitudinal distribution of catch data for minke whales in the Antarctic, Appendix 8. Rep. int. Whal. Commn 32: 712

Wada, S., Kobayashi, T., Numachí, K. (1991). Genetic variability and differentiation of mitochondrial DNA in minke whales. Rep. int. Whal Commn (Special Issue) 13: 203-215

Wada, S., Numachi, K. (1979). External and biochemical characters as an approach to stock identification for the Antarctic minke whale. Rep. int. Whal. Commn 29 . $421-432$

Williamson, G. R. (1975). Minke whales off Brazil. Sci. Rep. Whales Res. Inst. 27: 37-59

Manuscript first received: June 28, 1994

Revised version accepted: December 9, 1994 